\title{
Cryopreservation of Genetic Diversity in Rabbit Species (Oryctolagus cuniculus)
}

\author{
Thierry Joly, Vanessa Neto and Pascal Salvetti \\ Université de Lyon, France, VetAgro Sup - Isaralyon, \\ UPSP ICE 'Interactions between Cells and their Environment', Team Cryobio \\ France
}

\section{Introduction}

After the ratification of the international convention on the biodiversity in Rio, a National Cryobank was created in France in 1999 to preserve the genetic resources of domestic animals (www.cryobanque.org). Particular attention was carried on Oryctolagus cuniculus species with the extension of the national cryobanking to the rabbit (Joly et al., 1998). Nowadays, this tool is very useful for the management of animal diversity in France.

Cryopreservation corresponds of all the steps of collection and long term storage of animal populations, preserved as live cells and able to generate live animals.

Cryopreservation is not a museology action to freeze the products of the past. Contrary to that, it corresponds to the practical implementation of new biotechnologies of reproduction. It includes also all the technical means to maintain the evolutionary potential of population. So, the French National Cryobank was created to secure the biological material stored at $196^{\circ} \mathrm{C}$ in liquid nitrogen. It constitutes a real tool to serve all stakeholders to manage the animal diversity as part of the National Charter supported by the Genetic Resources Office (www.fondationbiodiversite.fr).

\section{Genetic diversity in rabbit species}

The archaeological origins of rabbit are located in Spain (Bolet et al., 2000). Actually, rabbit is widely spread all around the world and can be considered according situations as wild animal, domestic animal, pets and laboratory models. The rabbit populations can be classified into 3 categories according to their genetic originality, their specific uses and the motivations of breeders involved in the in situ management of populations (figure 1).

\section{1 "Type I" material}

Type I regroups the breeds identified according to an official standard, as well as for large breeds (Butterfly, Champagne Argente, Fauve de Bourgogne...) and endangered breeds with less than 100 females (Brun Marron de Lorraine ...). These breeds are reared by fancy breeders and animals are presented regularly in local or regional meetings supported by FFC the federation of French fancy rabbit breeders (www.ffc.asso.fr). These breeds must be preserved for their patrimonial values and socio cultural interests. 


\section{2 "Type II" material}

Type II concerns animals with one or more specific character:

- Animals carrying an identified gene (The recessive gene Sam in "jumper Alfort rabbit" evidenced by a modified walking on anterior legs; new transgenic lines recently created)

- Animals showing a specific combination of genes (histocompatible lines; allotypic strains from Basel having used as model for histocompatibility major complex studies)

- Animals with a particular genotype from a high selected population but not from the actual breeding schemes (black Orylag rabbit and Rex albinos presenting colours differing from the selected population, the divergent strain Inra 1029 made of two foetal mortality rate-diverging lines).

Most of Type II populations mainly have a scientific interest with high experimental values. Some populations could be promoted in biomedical research and by the pharmaceutical industry.

\section{3 "Type III" material}

Type III regroups all the populations of rabbits selected for meat production (female lines and male lines) or fur production with high economic value.

Some strains are today completely extinct and subsist only under embryo-frozen form waiting for a possible perspective of reuse or selection scheme reorientation (Dutch hymalayan, Orylag, INRA 1077 female strains...).

Other populations are still selected and the frozen biologic material represents a selection control to measure genetic progress precisely. Moreover, for security, several populations commercially spread are subject to regular cryoconservation in order to save the selection core from a sanitary risk (Inra 2066, commercial lines of Hypharm and Hycole societies...)

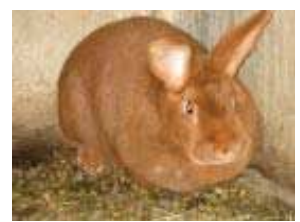

Rabbit « Fauve de

Bourgogne » (type I) adapted to a

traditionnal breeding system

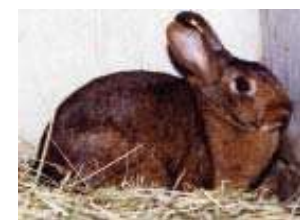

Rabbit « Brun Marron de Lorraine » (type I), endangered breed

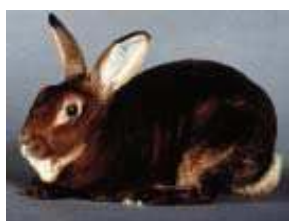

Rabbit « Orylag® castor (type III) bred for its "Rex" fur

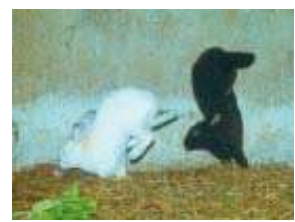

Rabbit "Sauteurs

d'Alfort" (type II).

They move on forlegs

when they are stressed

Fig. 1. Examples of different categories of rabbits

\section{Principal ways of cryoconservation of rabbit genetic resources}

To keep rabbit genetic resources, we can distinguish three principal ways according to the nature of frozen biological material (Figure 2). 


\subsection{Germinal cells}

Based on the conservation of germinal cells, this way helps to conserve the gene pool of particular male or female individuals.

Mature spermatozoids (sperm collected in artificial vaginas) or immature (epididymal spermatozoids, spermatogonies in gonadic tissue) helps to save the male line. The freezing of an individual's semen (n generation) helps to obtain progeny $(n+1$ generation) after thawing and artificial insemination (AI) of females.

Semen samples of bad quality can be promoted by new technologies of in vitro fertilization (FIV) or intracytoplasmic sperm injection (ICSI), which then permits in vitro embryo production and progeny delivering after embryo transfer in synchronized recipient female (Daniel et al, 2007). Nowadays, semen freezing is not a reliable or repeatable method yet, and results after AI with rabbit frozen semen are still too inconstant to plan a routine utilization of this technique (Vicente et al, 1996; Moce et al, 2003). Only half of the sampled males can produce semen with freezable quality and approximately $50 \%$ of females give birth after insemination of thawed semen with a large variability [15\% 80\%]. However, this is the only available method to preserve precious males semen, mainly for type I and II.

Mature oocytes (picked up in oviduct 15 hours after ovulation) or immature oocytes (present in follicles of ovarian tissue) permits to save genetic resources by female way and to preserve cytoplasmic heredity. Mature oocytes freezing of a female individu (n generation) would permit to obtain progenies ( $\mathrm{n}+1$ generation) after FIV or ICSI, but no young rabbit has been obtained from thawed oocytes yet (Salvetti et al, 2010). But, recently, young rabbits obtained from frozen ovarian tissue are born from females transplanted by orthotopic autograft (Almodin et al., 2004; Neto et al., 2007). In emergency situations (sanitary problems, injured animals), ovarian cortex freezing, even if this method is not yet completely under control (Neto et al., 2008), can be proposed to save the heredity pool of an important female of type II.

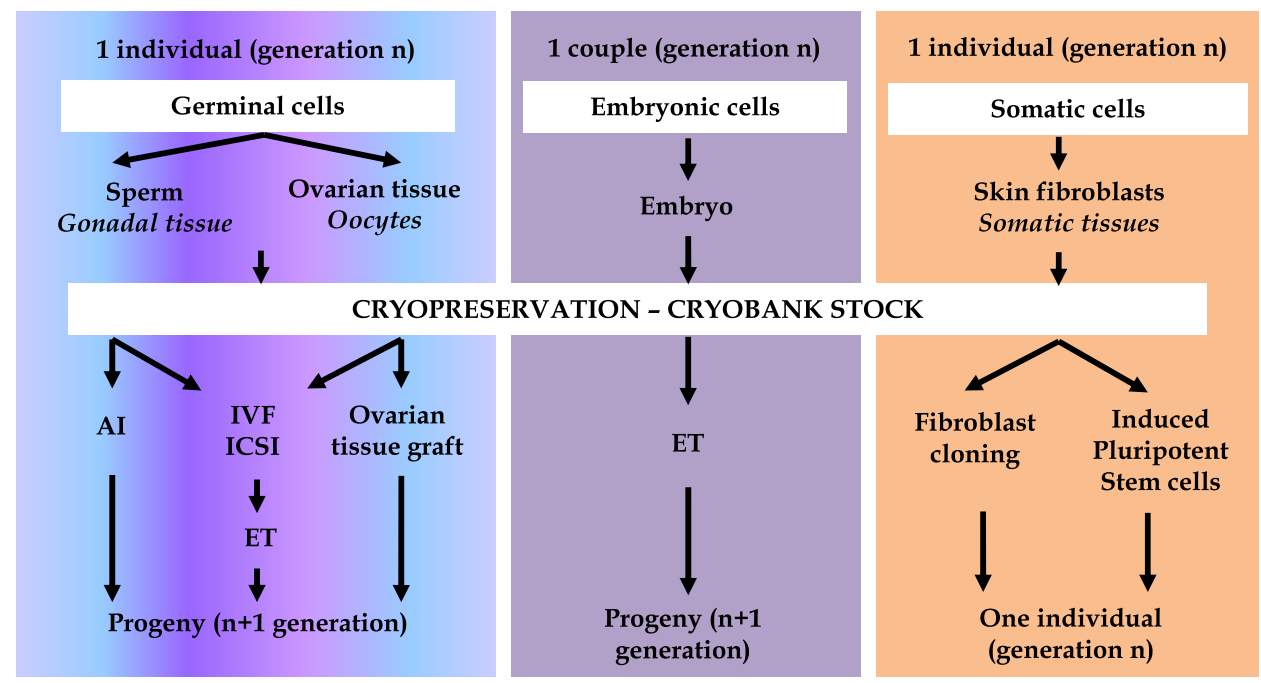

Fig. 2. Biotechnologies of reproduction applied to the cryopreservation of the rabbit genetic resources 


\subsection{Embryonic cells}

Embryo freezing, allowing the preservation of both male and female ways, is the main way to recreate quickly a population from thawed embryo transfer. Most of the time, embryos are frozen at compacted morula stage (65h 72h post coitum) even if freezing at earlier stage (4 cells stage) is possible. They can be produced in vivo from superovulated females or not, or in vitro after In Vitro Fertilization and in vitro culture. Embryos freezing from a planned mating ( at $n$ generation) permits to obtain progenies (at $n+1$ generation) after thawing and transfer in recipient females.

\subsection{Somatic cells}

This way has the main advantage of being easy to do, which permits to sample tissues quickly and simply on a large number of individuals. But the main difficulty is the recreation of animals after somatic cloning, still not well controlled. The cells can be isolated from different tissues: skin, cartilage, bones, blood... These cells, present in a large number in each organism, would allow the reconstitution of an individual of the same generation than the tissues giver after somatic cloning (Chesne et al., 2002).

More recently, a new opportunity came with induced pluripotent stem cells, which are able to differentiate in many tissues. These cells are potential vectors for genetic traits transmission and could be used after thawing as an important core source to regenerate many individuals after nuclear transfer (Honda et al, 2010).

\section{Frozen embryo, the main way for rabbit cryoconservation}

The embryo is the favored biological material to conserve most of rabbit populations, by both male and female ways, and then preserve cytoplasmic heredity. This method has been widely proved for 15 years with more than 32000 produced embryos but can only be applied to living and fertile animals.

\subsection{Embryos production}

As rabbit is naturally prolific species, two methods can be used to produce embryos:

- Without ovarian stimulation: one single injection of a GnRH analog (gonadotropic hormon) induces females ovulation at the same time as artificial insemination. Sometimes, an injection of 20-30 UI of eCG (equine chorionic gonadotrophin) three days before mating increases the females receptivity, especially the sexual resting ones;

- With ovarian stimulation by superovulation: a three days treatment of FSH injection stimulates the ovarian activity and increases the number of produced embryos per donor female ( Kauffman et al, 1998; Salvetti et al., 2007).

Overall, $73 \%$ of the treated and collected females are embryos donors and produce an average of 9.2 embryos without ovarian stimulation or with a slight eCG stimulation, and two to three times more (21.2 embryos) after a superovulation treatment (table 1). The embryo recovering rates (number of collected embryos/number of corpus luteum) are between $70 \%$ and $80 \%$ and those of freezable embryos (number of frozen embryos/number of collected embryos) are from $75 \%$ to $85 \%$. 


\begin{tabular}{|c|c|c|c|c|}
\hline Treatment & $\begin{array}{c}\text { Nb of treated } \\
\text { females }\end{array}$ & \% donor & $\begin{array}{c}\text { Nb of frozen } \\
\text { embryos }\end{array}$ & $\begin{array}{c}\text { Nb of embryos } \\
\text { per donor }\end{array}$ \\
\hline $\begin{array}{c}\text { No ovarian } \\
\text { stimulation }\end{array}$ & 1226 & $77 \%$ & 8633 & 9.2 \\
\hline $\begin{array}{c}\text { Superovulation } \\
\text { (FSH) }\end{array}$ & 1589 & $71 \%$ & 23833 & 21.2 \\
\hline Total & $\mathbf{2 8 1 5}$ & $\mathbf{7 3 \%}$ & $\mathbf{3 2 4 6 6}$ & \\
\hline
\end{tabular}

Table 1. Method of embryo production (activity from 1998 to 2011)

\subsection{Embryos recovering and freezing}

Slaughter the females with uterine tract washing is the most effective method to collect rabbit embryos. This method is simple and easy to implement directly on the breeding place of the animals. Cryoconservation of a population, about 40 to 50 females is feasible in one single day. The method is to keep for large population of type I and III because of systematic slaughter of females.

In addition, a new method of embryos collection by endoscopy allows renewing about four times the operation on the same female, preserving the female's integrity (Garcia et al., 1991; Besenfelder et al., 1998). A lot heavier to implement, it is reserved to rare and precious animals of type II or to small effective populations of type I.

Embryos were frozen in the same cryoprotective solution containing 1.5 M DMSO and by the same slow freezing process, even more vitrification could provide good results but this method is not totally under control (Mehaisen et al., 2006).

\subsection{Embryo transfer and births}

After thawing of a part of these embryos, the embryo transfer results vary according to the environmental conditions defined by the recipient female genotype and breeding conditions (table 2).

\begin{tabular}{|c|c|c|c|c|c|}
\hline $\begin{array}{c}\text { Transfer } \\
\text { conditions }\end{array}$ & $\begin{array}{c}\text { Nb of } \\
\text { recipients }\end{array}$ & $\begin{array}{c}\text { \% of } \\
\text { delivering } \\
\text { female }\end{array}$ & $\begin{array}{c}\text { Nb of thawed } \\
\text { embryos }\end{array}$ & $\begin{array}{c}\text { Nb of } \\
\text { borned pups }\end{array}$ & $\begin{array}{c}\text { Embryo } \\
\text { developmental } \\
\text { rate }\end{array}$ \\
\hline $\begin{array}{c}\text { Standard } \\
\text { controlled }\end{array}$ & 277 & $82 \%$ & 2746 & 1118 & $41 \%$ \\
\hline $\begin{array}{c}\text { On Field } \\
\text { transfer }\end{array}$ & 87 & $56 \%$ & 846 & 176 & $21 \%$ \\
\hline Total & $\mathbf{3 6 4}$ & $\mathbf{7 6 \%}$ & $\mathbf{3 5 9 2}$ & $\mathbf{1 2 9 4}$ & $\mathbf{3 6 \%}$ \\
\hline
\end{tabular}

Table 2. Pups production after transfer of thawed embryos (activity from 1998 to 2011)

The optimal environmental conditions are defined by the recipient from a mother female line placed in a control environment in an aboveground breeding (16 hours of light per day), 
while uncontrolled conditions are defined by a recipient placed in an uncontrolled environment (sanitary, light, temperature) in a traditional farm's breeding conditions.

Globally, $76 \%$ of the recipients give birth to young rabbits after thawed embryo transfer with an embryo development rate of $36 \%$. It is particularly important to control the recipient's genotype and the breeding conditions in order to guarantee the population recreation after cryoconservation.

The efficiency of the cryoconservation method has been concretely proved after transfer of embryos stored for more than 15 years in liquid nitrogen. In November 2006, 69 Brun Marron de Lorraine young rabbits got born after thawing and transfer of 134 embryos in recipients. The young rabbits born from frozen embryos of 1992 were presented to public at the international agriculture show in Paris in March 2007, in collaboration with fancy breeders and the FFC (Salvetti et al., 2007).

\section{The national cryobank: A saving tool of rabbit genetic resources}

In March 2008, the rabbit collections presented a large genetic diversity, which could be ranged according to three types of materials previously defined. Nearly sixty of rabbit populations have been cryopreserved. More than 19.000 embryos from about 1.300 rabbit doe donor have been frozen and are currently stored in liquid nitrogen at $-196^{\circ} \mathrm{C}$. For all these populations, three methods of embryos production have been applied according to the situation and the physiological state of rabbit does (superovulation, eCG, simple induction of ovulation). Then, all these embryos were treated according to the same freezing protocol (Joly et al, 1998). All the actors working for the rabbit populations management are henceforth convinced of the interest of this tool. They have actively participated to the building of the rabbit French cryobank. Public and private selectors, associations of fancy breeders and different groups of independent breeders are regular depositor.

\section{A reality}

The patrimonial cryobank for rabbit species is henceforth a reality. It allows to satisfy the expectations of breeders, selectors and the actors of research and biomedical industries. This last actor takes a more and more important rules in the rabbit production.

A standard method of rabbit embryos cryopreservation has been routinely applied for 15 years. Its implementation is performed on the field with a portative controlled rate freezer. This method requires a simple stimulation of the females before the collection, and an appropriate choice of the males for the breeding combinations. However, the complete conditions are not always encountered and this method is not efficient in emergency situation (for example, when an animal is rugged or during sanitary crisis).

So, another complementary methods are studied. These new way of research includes the cryopreservation of testicular tissue and epididymal spermatozoa in the male which are dead for less than two days. It includes also the cryopreservation of the rabbit ovarian tissue. Nowadays, the freezing of ear's fibroblasts is studying to produce Induced Pluripotent Stem Cells in order to use it for chimaeric animal production as tool of regeneration of initial population without genetic drift. 


\section{References}

Almodin, C.G., Minguetti-Camara, V.C., Meister, H., Ferreira, J.O., Franco, R.L., Cavalcante, A.A., Radaelli, M.R., Bahls, A.S., Moron, A.F., Murta, C.G. (2004). Recovery of fertility after grafting of cryopreserved germinative tissue in female rabbits following radiotherapy. Hum Reprod, Vol.19, No.6, pp:1287-1293,

Besenfelder, U., Strouhal, C., Brem, G. (1998). A method for endoscopic embryo collection and transfer in the rabbit. Zentralbl Veterinarmed A, Vol.45, No.9, pp: 577-579,

Bolet, G., Monnerot, M., Arnal, C., Arnold, J., Belle, D., Bergoglio, G., Besenfelder, U., Bosze, S., Boucher, S., Brun, J.M., Chanteloup, N., Ducourouble, M.C., Durand-Tardif, M., Esteves, P.J., Ferrand, N., Hewitt, G., Joly, T., Koehl, P.F., Laube, M., Lechevestrier, S., Lopez, M., Masoero, G., Piccinin, R., Queney, G., Saleil, G., Surridge, A., Van Der Loo, W., Vanhommerig, J., Vicente, J.S., Virag, G., Zimmermann, J.M. (2000). Evaluation and conservation of european rabbit genetic resources : first results and inferences. World rabbit Science, Vol. 8, pp:281-315,

Chesne, P., Adenot, P.G., Viglietta, C., Baratte, M., Boulanger, L., Renard, J.P. (2002). Cloned rabbits produced by nuclear transfer from adult somatic cells. Nat Biotechnol, Vol.20, pp:366-369,

Daniel, N., Chesne, P., Baratte, M., Renard, J.P. (2007). Lapins produits par injection intracytoplasmique de spermatozoïdes (ICSI) stockés à température ambiante. 12èmes Journées de la Recherche Cunicole, Le Mans, France, pp.33-36,

Garcia-Ximenez, F., Vicente, J.S., Santacreu, M.A. (1991). Embryo transfer in lactating rabbit does by laparoscopy. Anim Reprod Sci, Vol.24, pp:343-346,

Honda, A., Hirose, M., Hatori, M., Matoba, S., Miyoshi, H., Inoue, K., Ogura, A. (2010). Generation of Induced Pluripotent Stem Cells in Rabbits : Potential experimental models for human regenerative medicine. J. Biol. Chem. Vol.285, pp :31362-31369,

Joly, T., Rochambeau, H. de., Renard, J.P. (1998). Etablissement d'une cryobanque d'embryons pour la conservation ex situ de la diversité génétique chez le lapin : aspects pratiques. Genet.Sel.Evol. Vol.30, No.1, pp:259-269,

Kauffman, R.D., Schmidt, P.M., Rall, W.F., Hoeg, J.M. (1998). Superovulation of rabbits with FSH alters in vivo development of vitrified morulae. Theriogenology, Vol. 50, pp: 1081-1092,

Mehaisen, G.M.K., Viudes-de-Castro, M.P., Vicente, J.S., Lavara, R. (2006). In vitro and in vivo viability of vitrified and non-vitrified embryos derived from eCG and FSH treatment in rabbit does. Theriogenology, Vol.65, pp:1279-1291,

Mocé, E., Vicente, J.S., Lavara, R. (2003). Effect of freezing-thawing protocols on the performance of semen from three rabbit lines after artificial insemination. Theriogenology, Vol.60, pp:115-123,

Neto, V., Joly, T., Salvetti, P., Lefranc, A.C., Corrao, N., Buff, S., Guérin, P. (2007). Ovarian tissue cryopreservation in the doe rabbit: from freezing to birth. Cryobiology, Vol.55, pp:344,

Neto, V., Buff, S., Lornage, J., Bottollier, B., Guerin, P., Joly, T. (2008). Effects of different freezing parameters on the morphology and viability of preantral follicles after cryopreservation of doe rabbit ovarian tissue. Fertil. Steril. Vol.89, No.3, pp:13481356 , 
Salvetti, P., Joly, T., Boucher, S., Hurtaud, J., Renard, JP. (2007). Viability of rabbit embryos after 15 years storage in liquid nitrogen. 44th Annual Meeting of the Society for Cryobiology CRYO 2007, Lake Louise, Canada,

Salvetti, P., Theau-Clement, M., Beckers, J.F., Hurtaud, J., Guerin, P., Neto, V., Falieres, J., Joly, T. (2007). Effect of the luteinizing hormone on embryo production in superovulated rabbit does. Theriogenology, Vol.67, pp:1185-1193,

Salvetti, P., Buff, S., Afanassieff, M., Daniel, N., Guérin, P., Joly, T. (2010). Structural, metabolic and developmental evaluation of ovulated rabbit oocytes before and after cryopreservation by vitrification and slow freezing. Theriogenology, Vol.74, pp:847 - 855,

Vicente, J.S., Viudes-de-Castro, M.P. (1996). A sucrose-DMSO extender for freezing rabbit semen. Reprod Nutr Dev. Vol.36, No.5, pp:485-492. 


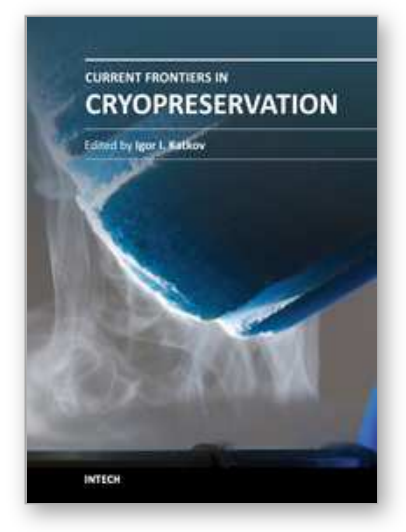

\author{
Current Frontiers in Cryopreservation \\ Edited by Prof. Igor Katkov
}

ISBN 978-953-51-0302-8

Hard cover, 462 pages

Publisher InTech

Published online 14, March, 2012

Published in print edition March, 2012

Almost a decade has passed since the last textbook on the science of cryobiology, Life in the Frozen State, was published. Recently, there have been some serious tectonic shifts in cryobiology which were perhaps not seen on the surface but will have a profound effect on both the future of cryobiology and the development of new cryopreservation methods. We feel that it is time to revise the previous paradigms and dogmas, discuss the conceptually new cryobiological ideas, and introduce the recently emerged practical protocols for cryopreservation. The present books, "Current Frontiers in Cryobiology" and "Current Frontiers in Cryopreservation" will serve the purpose. This is a global effort by scientists from 27 countries from all continents and we hope it will be interesting to a wide audience.

\title{
How to reference
}

In order to correctly reference this scholarly work, feel free to copy and paste the following:

Thierry Joly, Vanessa Neto and Pascal Salvetti (2012). Cryopreservation of Genetic Diversity in Rabbit Species (Oryctolagus cuniculus), Current Frontiers in Cryopreservation, Prof. Igor Katkov (Ed.), ISBN: 978-953-510302-8, InTech, Available from: http://www.intechopen.com/books/current-frontiers-incryopreservation/cryopreservation-of-genetic-diversity-in-rabbit-species

\section{INTECH}

open science | open minds

\section{InTech Europe}

University Campus STeP Ri

Slavka Krautzeka 83/A

51000 Rijeka, Croatia

Phone: +385 (51) 770447

Fax: +385 (51) 686166

www.intechopen.com

\section{InTech China}

Unit 405, Office Block, Hotel Equatorial Shanghai

No.65, Yan An Road (West), Shanghai, 200040, China 中国上海市延安西路65号上海国际贵都大饭店办公楼 405 单元

Phone: +86-21-62489820

Fax: +86-21-62489821 
(C) 2012 The Author(s). Licensee IntechOpen. This is an open access article distributed under the terms of the Creative Commons Attribution 3.0 License, which permits unrestricted use, distribution, and reproduction in any medium, provided the original work is properly cited. 